\section{Ocular finding in Zika virus infection}

\section{Achados oftalmológicos em infecções pelo vírus Zika}

\section{Dear Editor:}

The recent report on the Zika virus infection was very interesting ${ }^{(1)}$. Ventura et al. concluded that "patients presented with normal anterior segment and important macular and optic nerve abnormalities"(1). I would like to share my ideas and experience on this finding. There is no doubt that the Zika virus directly invades the nervous system, ${ }_{1}^{(2)}$ and neuro-ophthalmological problems can be seen. Nevertheless, it is still unclear whether ocular findings are caused by pathological processes that occurred prior to the Zika virus infection. As an acute dengue and like any illness, there are many pathological processes that can affect the eye including high fever, hemorrhage, and autoimmunity ${ }^{(3-4)}$. Although there is a previous autopsy report on infected cases $^{(2)}$, it does not include an assessment of ocular tissue. In Thailand, a tropical country where the Zika virus infection has already been reported, there are still no reports of ocular problems in affected cases ${ }^{(3,5)}$. Nevertheless, the ocular problem in Zika virus infection is an issue for further study, particularly its epidemiology and pathogenesis.

Viroj Wiwanitkit ${ }^{1-4}$

\footnotetext{
Hainan Medical University, Haikou, Hainan, China.

Faculty of Medicine, University of Nis, Nis, Serbia.

Joseph Ayobabalola University, llesa, Osun State, Nigeria.

Dr DY Patil Medical University, Pimpri, Maharashtra, India.

Corresponding author: Viroj Wiwanitkit. Wiwanitkit House - Bangkhae, Bangkok, 10160, Thailand E-mail: wviroj@yahoo.com
}

\section{REFERENCES}

1. Ventura CV, Maia M, Ventura BV, Linden WV, Araújo EB, Ramos RC, et al. Ophthalmological findings in infants with microcephaly and presumable intra-uterus Zika virus infection. Arq Bras Oftalmol. 2016:79(1):1-3.

2. Mlakar J, Korva M, Tul N, Popović M, Poljšak-Prijatelj M, Mraz J, et al. Zika Virus associated with microcephaly. N Engl J Med. 2016;374(10):951-8.

3. Joob B, Wiwanitkit V. Zika virus infection and dengue: A new problem in diagnosis in a dengue-endemic area. Ann Trop Med Public Health. 2015;8(4):145-6.

4. Wiwanitkit S, Wiwanitkit V. Acute viral hemorrhage disease: A summary on new viruses. J Acute Dis. 2015:4(4):277-9.

5. Buathong R, Hermann L, Thaisomboonsuk B, Rutvisuttinunt W, Klungthong C, Chinnawirotpisan $\mathrm{P}$, et al. Detection of Zika virus infection in Thailand, 2012-2014. Am J Trop Med Hyg. 2015;93(2):380-3.

\section{Response letter:}

\section{Serological evidence confirms the} presumed diagnosis of Zika virus congenital infection in infants with microcephaly and ocular findings

\section{Resposta da carta: \\ Evidência sorológica confirma diagnóstico presumido de infecção congênita por vírus Zika em crianças com microcefalia e achados oculares}

We read with interest the letter by Dr. Wiwanitkit. It is surprising that other countries that have had cases of the Zika virus (ZIKV) infection have not had any cases of congenital Zika virus infection $(C Z V I)$, even after the virus spread to more than 20 countries, including countries in America ${ }^{(1)}$. However, there is no doubt that the multiple systemic findings encountered in these infants are caused by ZIKV intra-uterus. Recently, Cugola et al. proved that the Brazilian Zika virus strain causes birth defects in experimental mice models by crossing the placenta and by targeting cortical progenitor cells, inducing cell death by apoptosis and autophagy, and impairing neurodevelopment ${ }^{(2)}$.

Regarding the ocular involvement in these infants, our group was the first to report these findings, followed by De Paula Freitas et al. who described similar findings in infants with microcephaly in Bahia State, another northeastern state of Brazil ${ }^{(3-5)}$.

In fact, not long ago, we were able to perform cerebrospinal fluid (CSF) testing in six of the 10 infants with Zika virus infection from our study ${ }^{(3)}$; all six infants were positive for ZIKV infection, which confirmed the diagnosis of CZVI.

Furthermore, our group recently published another study analyzing the variables related to the ophthalmoscopic findings in these infants with suspicion of CZVI. Twenty-four (60\%) of them were tested for Zika virus infection and all were positive ${ }^{(6)}$.

Although we are progressing in our scientific knowledge of ZIKV, countless questions remain unanswered; one of these questions is the pathogenesis of these ocular lesions.

\author{
Camila V. Ventura ${ }^{1,2,3}$ \\ Mauricio Maia ${ }^{3,4}$ \\ Bruna V. Ventura', ${ }^{1,3}$, \\ Vanessa V. D. Linden ${ }^{5}$ \\ Eveline B. Araújo ${ }^{1,2}$ \\ Regina C. Ramos ${ }^{6}$ \\ Maria Angela W. Rocha6, \\ Durce C. G. Carvalho', \\ Rubens Belfort Jr. ${ }^{3,4}$ \\ Liana O. Ventura ${ }^{1,2}$
}

Submitted for publication: May 23, 2016 Accepted for publication: May 23, 2016

Fundação Altino Ventura (FAV), Recife, PE, Brazil.

2 Hospital de Olhos HOPE, Recife, PE, Brazil.

Department of Ophthalmology and Visual Science, Escola Paulista de Medicina (EPM), Universidade Federal de São Paulo (UNIFESP), São Paulo, SP, Brazil.

${ }^{4}$ Instituto da Visião, São Paulo, SP, Brazil.

5 Hospital Barão de Lucena, Recife, PE, Brazil.

Hospital Universitário Osvaldo Cruz (HUOC), Recife, PE, Brazil.

Funding: No specific financial support was available for this study.

Disclosure of potential conflicts of interest: None of the authors have any potential conflict of interest to disclose.

Corresponding author: Rubens Belfort Jr. Departamento de Oftalmologia - Escola Paulista de Medicina. Rua Botucatu, 831-São Paulo, SP - 04023-062 - Brazil - E-mail: clinbelf@uol.com.br

\section{REFERENCES}

1. Yakob L, Walter T. Zika virus outbreak in the Americas: the need for novel mosquito control methods. Lancet Glob Health. 2016

2. Cugola FR, Fernandes IR, Russo FB, et al. The Brazilian Zika virus strain causes birth defects in experimental models. Nature. 2016

3. Ventura CV, Maia M, Ventura BV, et al. Ophthalmologic findings in infants with microcephaly and presumable intra-uterus Zika virus infection. Arq Bras Oftalmol. 2016; 79(1):1-3.

4. Ventura CV, Maia M, Bravo-Filho V, Gois AL, Belfort Jr R. Zika virus in Brazil and macular atrophy in a child with microcephaly. Lancet. 2016:387(10015):228. de Paula Freitas B, de Oliveira Dias JR, Prazeres J, et al. Ocular findings in infants with microcephaly associated with presumed zika virus congenital infection in Salvador, Brazil. JAMA Ophthalmol. 2016

5. Ventura CV, Maia M, Travassos SB, et al. Variables related to the ophthalmoscopic findings identified in infants with presumed Zika virus congenital infection. JAMA. 2016. In press. 